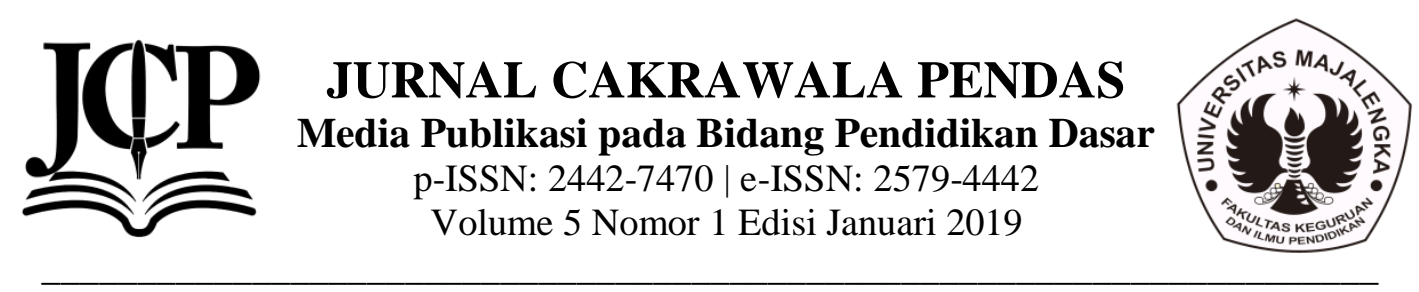

\title{
PENERAPAN MODEL PEMBELAJARAN KOOPERATIF TIPE TAI (TEAM ASSISTED INDIVIDUALIZATION) UNTUK MENINGKATKAN HASIL BELAJAR SISWA PADA MATA PELAJARAN MATEMATIKA
}

\author{
Ujiati Cahyaningsih \\ ujiati.cahyaningsih31@gmail.com \\ Universitas Majalengka
}

\begin{abstract}
ABSTRAK
Penelitian ini dilatarbelakangi masih rendahnya hasil belajar siswa pada kelas V SDN Sukarajakulon I mata pelajaran matematika, dari pembelajaran yang hanya menggunakan model konvensional dan hanya mencapai nilai rata-rata 67,75 dengan presentase ketuntasan 42,5\%. Untuk mengatasi permasalahan tersebut dilakukan Penelitian Tindakan Kelas yang bertujuan untuk meningkatkan hasil belajar siswa pada mata pelajaran matematika di Kelas V SDN Sukarajakulon I melalui penerapan model pembelajaran kooperatif tipe TAI (Team Assisted Individualization). Dalam penelitian ini, peneliti bekerjasama dengan guru kelas V SDN Sukarajakulon I sebagai observer. Subjek penelitian adalah siswa kelas V SDN Sukarajakulon I, sebanyak 40 siswa terdiri dari 20 siswa laki-laki dan 20 siswa perempuan. Teknik yang digunakan dalam pengumpulan data adalah tes, observasi, dan wawancara. Data yang diperoleh berupa hasil tes sebagai data primer dan hasil observasi serta wawancara sebagai data sekunder. Teknik analisis data yang digunakan adalah analisis data kuantitatif untuk menganalisis hasil tes akhir pada setiap siklus dan analisis data kualitatif untuk hasil observasi setiap siklus. Penelitian dilaksanakan dalam dua siklus. Hasil penelitian menunjukkan nilai rata-rata kelas yang diperoleh siswa sebelum tindakan adalah 67,75 dengan presentase ketuntasan 42,5\% atau 17 siswa yang tuntas, sedangkan presentase ketuntasan siswa pada siklus I adalah $70 \%$ atau 28 siswa yang tuntas, dengan nilai rata-rata kelas yang diperoleh siswa adalah 70,375, dan pada siklus II nilai rata-rata kelas yang diperoleh siswa adalah 97,375 sedangkan presentase siswa yang memperoleh nilai mencapai ketuntasan belajar adalah $95 \%$ atau 38 siswa yang tuntas. Kesimpulan, bahwa penerapan model pembelajaran kooperatif tipe TAI (Team Assisted Individualization) dapat meningkatkan hasil belajar siswa pada mata pelajaran matematika materi kesebangunan dan simetri di kelas V SDN Sukarajakulon I Kecamatan Jatiwangi Kabupaten Majalengka Tahun Ajaran 2015/2016.
\end{abstract}

Kata Kunci : Hasil Belajar Siswa, Model Pembelajaran Kooperatif Tipe TAI (Team Assisted Individualization). 


\section{Pendahuluan}

Suatu pendidikan yang ideal adalah pendidikan yang mampu meningkatkan perkembangan belajar siswa yang mencakup multi ranah, baik ranah kognitif, afektif dan psikomotor. Pembangunan karakter siswa juga perlu diperhatikan agar pendidikan tidak hanya menciptakan manusia yang unggul secara akademis tetapi juga manusia yang bermoral baik. Ungkapan tersebut diatas relevan dengan fungsi pendidikan nasional dalam Undang-Undang Republik Indonesia Nomor 20 Tahun 2003 tentang Sistem Pendidikan Nasional.

Berdasarkan dari tujuan pendidikan yang telah menjadi kebijakan pemerintah, tugas guru tidak hanya berperan sebagai pengajar yang hanya mentransferkan ilmu ke siswa melainkan sebagai seorang pendidik yang berkewajiban mengembangkan seluruh potensi yang dimiliki siswa. Salah satu yang dapat guru lakukan agar dapat meningkatkan kualitas pembelajaran yaitu dengan memahami karakteristik siswa. Guru harus dapat memahami cara siswa belajar agar dapat menentukan model pembelajaran yang tepat sehingga tujuan pembelajaran tercapai dengan baik.

Menurut Siswanto dan Palupi (2013:77) "Model Pembelajaran Kooperatif TAI (Team Assisted Individualization) merupakan pembelajaran yang mengkombinasikan antara belajar kooperatif dengan belajar individual". Menurut Slavin (Huda, 2014:200) "Model Pembelajaran

Kooperatif TAI (Team Assisted Individualization) merupakan sebuah program pedagogik yang berusaha mengadaptasi pembelajaran dengan perbedaan individual siswa secara akademik".

Menurut Sukmadinata (dalam Karwati dan Priansa, 2014:214) "Hasil belajar atau achievement merupakan realisasi atau pemekaran dari kecakapankecakapan potensial atau kapasitas yang dimiliki seseorang". Senada dengan pendapat Syam (2008:150) mengungkapkan bahwa, "Hasil belajar yang ideal meliputi ranah psikologis yang berubah sebagai akibat pengalaman dan proses belajar peserta didik". Menurut Reigulth (Suprihatiningrum, 2013:37) berpendapat bahwa, "Hasil belajar atau pembelajaran dapat juga dipakai sebagai pengaruh yang memberikan suatu ukuran nilai dari metode (strategi) alternative dalam kondisi yang berbeda".

Pembelajaran Matematika di Sekolah Dasar masih belum sesuai dengan standar proses pembelajaran seperti yang diamanatkan Permendiknas tersebut. Sebagai salah satu mata pelajaran yang penting, Matematika justru menjadi mata pelajaran yang kurang diminati siswa dan membuat siswa bingung dalam pembelajarannya. Serta Matematika juga merupakan mata pelajaran yang kebanyakan siswa beranggapan sulit untuk dipelajari, baik dalam konsep maupun dalam hal pembelajarannya di kelas.

Berdasarkan hasil wawancara dan observasi, peneliti memperoleh data bahwa siswa mengetahui tentang materi Matematika yang telah dipelajari, namun ketika siswa diberikan soal latihan terlihat mengalami kesulitan dalam pengerjaannya atau menjawab soal tersebut. Kendala yang dialami oleh siswa tersebut disebabkan karena siswa kurang dapat memahami tentang konsep dasar secara menyeluruh mengenai materi yang mereka pelajari. Terlihat kondisi siswa yang kurang kondusif dan pembelajaran yang kurang menyenangkan sehingga membuat siswa kurang terlibat aktif dalam pembelajaran. Hal ini disebabkan karena guru terbiasa menggunakan model konvensional seperti ceramah, tanya jawab dan latihan atau pemberian tugas. Dimana proses pembelajaran lebih terfokus pada guru, dan kurang melibatkan siswa secara aktif dalam proses pembelajaran, sehingga hasil belajar yang diperoleh siswa tidak maksimal. 
Salah satu bentuk pembelajaran yang menarik dalam upaya meningkatkan hasil belajar siswa adalah dengan menerapkan model pembelajaran Kooperatif tipe Team Assisted Individualization (TAI). Model Team Assisted Individualization (TAI) ini memberikan kesempatan kepada siswa untuk belajar secara mandiri dalam menyelesaikan masalah. Proses pembelajaran diawali dengan belajar secara individu terhadap materi pembelajaran yang sudah dipersiapkan oleh guru sebelumnya, kemudian siswa diberi latihan soal dan dikerjakan secara mandiri/individual. Selanjutnya hasil belajar individual dibawa ke kelompokkelompok yang sudah dibentuk untuk didiskusikan dan saling dibahas oleh anggota kelompok, dan semua anggota kelompok bertanggung jawab atas keseluruhan jawaban sebagai tanggung jawab bersama.

Tujuan dari kegiatan tersebut adalah melatih kerjasama dalam memecahkan masalah, mengurangi sifat egois, belajar menghargai pendapat teman, melatih bertanggung jawab dalam menyelesaikan tugas. Dari penerapan model Team Assisted Individualization (TAI) tersebut diharapkan siswa dapat lebih mudah memahami materi, jika ada materi yang sulit dapat diselesaikan bersama-sama serta diharapkan dapat meningkatkan hasil belajar siswa baik secara kognitif, afektif dan psikomotor. Adapun hasil belajar siswa dalam penelitian tindakan kelas yang dilakukan hanya pada ranah kognitif. Dan Indikator hasil belajar yang dipilih peneliti yaitu pada ranah cipta (kognitif) yang terdiri dari pengamatan, ingatan, pemahaman dan analisis. Dipilih indikator ini karena menyesuaikan dengan materi dan kemampuan siswa pada usia sekolah dasar.

Berdasarkan uraian di atas, maka rumusan masalah dalam penelitian ini sebagai berikut :
1. Bagaimana penerapan Model Pembelajaran Kooperatif Tipe Team Assisted Individualization (TAI) pada siswa kelas $\mathrm{V}$ mata pelajaran Matematika SD Negeri Sukarajakulon I Kecamatan Jatiwangi Kabupaten Majalengka?

2. Bagaimana hasil belajar siswa kelas V pada mata pelajaran Matematika di SD Negeri Sukarajakulon I Kecamatan Jatiwangi Kabupaten Majalengka?

3. Bagaimana peningkatan hasil belajar siswa setelah menggunakan Model Pembelajaran Kooperatif Tipe Team Assisted Individualization (TAI) di SD Negeri Sukarajakulon I Kecamatan Jatiwangi Kabupaten Majalengka?

Adapun tujuan penelitiannya adalah

1. Untuk mengetahui penerapan Model Pembelajaran Kooperatif Tipe Team Assisted Individualization (TAI) pada siswa kelas V mata pelajaran Matematika SD Negeri Sukarajakulon I Kecamatan Jatiwangi Kabupaten Majalengka.

2. Untuk mengetahui hasil belajar siswa kelas V pada mata pelajaran Matematika di SD Negeri Sukarajakulon I Kecamatan Jatiwangi Kabupaten Majalengka.

3. Untuk mengetahui peningkatan hasil belajar siswa setelah menggunakan Model Pembelajaran Kooperatif Tipe Team Assisted Individualization (TAI) di SD Negeri Sukarajakulon I Kecamatan Jatiwangi Kabupaten Majalengka.

Terdapat beberapa kontribusi yang di harapkan dari hasil penelitian ini. Penelitian ini diharapkan memberikan sumbangan pada dunia pendidikan dalam pengajaran Matematika untuk peningkatan hasil belajar siswa melalui Model Pembelajaran Kooperatif Tipe Team Assisted Individualization (TAI). Serta dapat memberikan kontribusi kepada strategi pembelajaran disekolah 
serta dapat mengoptimalkan kemampuan siswa.

\section{Metode Penelitian}

Penelitian dilakukan pada bulan Maret sampai bulan Juni 2016. Penelitian ini dilakukan di SD Negeri Sukarajakulon I Kec. Jatiwangi Kab. Majalengka Tahun Ajaran 2015/2016 pada siswa kelas V.

Subjek dalam penelitian ini adalah siswa kelas V SD Negeri Sukarajakulon I Kec. Jatiwangi Kab. Majalengka Tahun Ajaran 2015/2016 yang berjumlah 40 orang, yang terdiri dari 20 orang laki-laki dan 20 orang perempuan.

Sumber data dalam penelitian merupakan data dari hasi tes, observasi dan wawancara. Adapun data penelitian yang digunakan peneliti dalam penelitian ini dikelompokkan dalam dua jenis data yaitu data primer dan skunder

Teknik yang dipergunakan untuk mengumpulkan data dalam penelitian ini adalah teknik pengumpulan data Tes dan Non Tes.

Prosedur penelitian dengan menggunakan prosedur penelitian tindakan kelas (PTK). Penelitian tindakan kelas dibagi dalam dua siklus, masingmasing siklus terdiri dari perencanaan (planing), tindakan (acting), pengamatan (observing), serta refleksi (reflecting).

Penelitian ini menggunakan prosedur kerja dari Kemmis dan McTaggart yang terdiri dari empat tahap untuk setiap siklusnya, yaitu Perencanaan, Pelaksanaan, Pengamatan, dan Refleksi.

Penelitian ini merupakan jenis penelitian dasar (basic research). Metode penelitian yang digunakan dalam penelitian ini adalah metode verifikatif. Dalam penelitian ini dapat dikatakan termasuk kedalam jenis penelitian kuantitatif.

\section{Hasil Penelitian}

Berdasarkan penelitian tindakan kelas yang telah dilaksanakan oleh peneliti, maka data setiap siklus yang telah diperoleh dalam penelitian ini selanjutnya dideskripsikan, dianalisis, direfleksi kemudian disimpulkan untuk mengetahui tingkat ketercapaian tujuan pembelajaran serta mengetahui kelebihan dan kekurangan perlakuan atau tindakan yang telah dilaksanakan, untuk dijadikan acuan dalam rancang perbaikan pembelajaran yang telah dilakukan sebelumnya.

Hasil observasi awal sebelum tindakan, maka hasil belajar yang diperoleh siswa kelas $\mathrm{V}$ terdiri dari 40 siswa dan siswa yang tuntas hanya 17 siswa atau $42,5 \%$ dan 23 siswa atau $57,5 \%$ yang belum tuntas. Sehingga dalam data nilai awal ini diperoleh nilai rata-rata 67,75. Hal ini menjadi permasalahan yang kompleks dan suatu keprihatinan di mata peneliti, serta perlunya upaya untuk dapat meningkatkan hasil belajar siswa pada mata pelajaran matematika khususnya dalam materi kesebangunan dan simetri. Secara sadar, hal ini menjadi suatu permasalahan yang penting bagi peneliti untuk segera diatasi agar tidak timbul permasalahan yang lain.

\section{Pembahasan}

Berdasarkan data yang telah diperoleh peneliti dari evaluasi tes hasil belajar serta lembar observasi aktivitas guru dan aktivitas siswa yang telah dideskripsikan, dianalisis, dan kemudian direfleksi dan setiap tindakan dan setiap siklus yang telah peneliti lakukan, peneliti dapat menyimpulkan terdapat beberapa temuan evaluasi hasil terpenting dari penelitian yang telah dilaksanakan.

Model Pembelajaran Kooperatif Tipe TAI (Team Assisted Individualization) merupakan model pembelajaran yang memprioritaskan diskusi dalam kelompok dan tidak melupakan manfaat besar dalam pendampingan secara individu. Model ini cenderung memberikan tanggung jawab kepada siswa untuk berdiskusi secara berkelompok untuk memahami suatu materi, dengan tidak melupakan peran 
guru dalam pendampingan siswa yang kurang paham pada materi tersebut.

Berdasarkan kelebihan Model Pembelajaran Kooperatif Tipe TAI (Team Assisted Individualization) dan dengan hasil tindakan yang telah dilakukan maka dapat disimpulkan bahwa Penerapan Model Pembelajaran Kooperatif Tipe TAI (Team Assisted Individualization) dapat meningkatkan Hasil Belajar Siswa pada Mata Pelajaran Matematika materi Kesebangunan dan Simetri. Peran serta aktivitas guru dapat ditingkatkan dengan menggunakan model ini, sehingga guru tidak hanya melakukan penjelasan materi di depan kelas tetapi juga membimbing dan mendampingi siswa dalam kelompok. Peran setiap anggota kelompok maupun guru sangat mempengaruhi hasil belajar siswa, karena siswa yang sudah memahami materi pembelajaran membantu siswa lain yang belum memahami materi tersebut sehingga hasil belajarnya dapat meningkat. Karena pada prinsipnya Model Pembelajaran Kooperatif Tipe TAI (Team Assisted Individualization) ini suatu model dimana siswa yang pintar membantu siswa yang kurang.

Hasil pembelajaran tentang materi kesebangunan dan simetri dikelas $\mathrm{V}$ menggunakan model pembelajaran kooperatif tipe TAI (Team Assisted Individualization) berdasarkan hasil tes evaluasi yang dilakukan oleh siswa, nilai rata-rata yang diperoleh siswa setiap siklus adalah sebagai berikut, yaitu siklus I nilai rata-rata sebesar 80,875 dengan presentase ketuntasan $70 \%$, dan siklus II nilai rata-rata sebesar 97,375 dengan presentase ketuntasan 95\%. Dengan demikian, maka dapat disimpulkan bahwa pembelajaran Matematika materi kesebangunan dan simetri di kelas $\mathrm{V}$ dengan menggunakan model pembelajaran kooperatif tipe TAI (Team Assisted Individualization) dapat meningkatkan hasil belajar siswa.

\section{Simpulan}

Penerapan Model Pembelajaran Kooperatif Tipe TAI (Team Assisted Individualization) pada siswa kelas $\mathrm{V}$ mata pelajaran Matematika, dilaksanakan selama dua siklus dengan empat tindakan. Adapun pelaksanaan pembelajaran dilakukan sesuai dengan langkah-langkah Model Pembelajaran Kooperatif Tipe TAI (Team Assisted Individualization) yaitu, Pertama, Guru memberikan tugas kepada siswa untuk mempelajari materi pembelajaran secara individual yang sudah dipersiapkan oleh guru. Kedua, Guru memberikan kuis secara individual kepada siswa untuk mendapatkan skor dasar atau skor awal. Ketiga, Guru membentuk beberapa kelompok. Setiap kelompok terdiri dari 5 siswa dengan kemampuan yang berbeda-beda baik tingkat kemampuan tinggi, sedang, maupun rendah. Keempat, Hasil belajar siswa secara individual didiskusikan dalam kelompok. Kelima, Guru memfasilitasi siswa dalam membuat rangkuman, mengarahkan, dan memberikan penegasan pada materi pembelajaran yang telah dipelajari, Keenam, Guru memberikan kuis kepada siswa secara individual, dan Ketujuh, Guru memberi penghargaan pada kelompok berdasarkan perolehan nilai peningkatan hasil belajar individual dari skor dasar ke skor kuis berikutnya (terkini). Dengan menerapkan model tersebut diharapkan hasil belajar siswa pada mata pelajaran matematika dapat meningkat sesuai dengan nilai KKM yang terdapat pada Sekolah tersebut.

Hasil belajar siswa pada mata pelajaran matematika sebelum menerapkan Model Pembelajaran Kooperatif Tipe TAI (Team Assisted Individualization) yaitu dengan presentase ketuntasan sebesar $42,5 \%$ atau 17 siswa yang tuntas sedangkan $57,5 \%$ atau 23 siswa belum tuntas. Adapun pembelajaran dengan menerapkan Model Pembelajaran Kooperatif Tipe TAI (Team Assisted Individualization) ini hasil belajar pada siklus I diperoleh presentase 
ketuntasan sebesar $70 \%$ atau 28 siswa tuntas dan $30 \%$ atau 12 siswa belum tuntas, dan pada siklus II diperoleh presentase ketuntasan sebesar $95 \%$ atau 38 siswa tuntas dan $5 \%$ atau 2 siswa belum tuntas. Pelaksanaan pembelajaran dilaksanakan melalui tahapan siklus I dan siklus II berpedoman dari rencana pelaksanaan pembelajaran yang telah disusun sebelumnya.

Berdasarkan hasil belajar siswa yang diperoleh setelah menggunakan menerapkan Model Pembelajaran Kooperatif Tipe TAI (Team Assisted Individualization) menunjukkan peningkatan, terlihat dari data awal dengan presentase ketuntasan sebesar $42,5 \%$ dengan jumlah siswa mencapai KKM 17 siswa, sedangkan pada siklus I presentase ketuntasan sebesar 70\% dengan jumlah siswa mencapai KKM 28 siswa dan pada pelaksanaan siklus II presentase ketuntasan sebesar 95\% dengan jumlah siswa mencapai KKM 38 siswa. Dengan hasil belajar siswa pada siklus II yang diperoleh dengan nilai presentase ketuntasan yaitu $95 \%$ dimana nilai tersebut telah melebihi nilai presentase keberhasilan sebesar $75 \%$ maka siklus berhenti di siklus II dan dinyatakan bahwa penerapan Model Pembelajaran Kooperatif Tipe TAI (Team Assisted Individualization) berhasil meningkatkan hasil belajar siswa pada mata pelajaran Matematika materi kesebangunan dan simetri kelas V SD Negeri Sukarajakulon I.

\section{Daftar Pustaka}

Abidin.Y.(2016). Revitalisasi Penilaian Pembelajaran. Bandung: PT Refika Aditama

Adjie, N., et al. (2006). Konsep Dasar Matematika. Bandung: Upi Press.

Amri, S. (2013). Pengembangan \& Model Pembelajaran dalam Kurikulum 2013.
Surabaya:

Prestasi

Pustakaraya.

Arifin, Z. (2013). Evaluasi Pembelajaran. Bumi Siliwangi: PT.Remaja Rosdakarya.

Badruzaman. (2011). Penerapan Pembelajaran Kooperatif Tipe TAI (Team Assisted Individualization) dalam Pembelajaran Fiqih Untuk Meningkatkan Hasil Belajar Siswa MTs. Semarang: tidak diterbitkan.

Budianti. (2013). Penerapan Model Pembelajaran Kooperatif Tipe TAI (Team Assisted Individualization) Untuk Meningkatkan Hasil Belajar Mata Pelajaran Sains Pada Siswa Kelas IV SDN 3 Labuan Panimba. Sulawesi Tengah: tidak diterbitkan.

Depdiknas. (2003). Undang-undang Republik Indonesia No. 20 Tahun 2003 Tentang Sistem Pendidikan Nasional. Bandung: Citra Umbara.

DePorter. B. (2010). Quantum Teaching. Bandung: Kaifa

Ekawati, E. (2011). Peran, Fungsi, Tujuan dan Karakteristik Matematika Sekolah. Bandung: Citra Umbara.

Fathurrohman, et al. (2011). Strategi Belajar Mengajar. Bandung: PT Refika Aditama.

Fatimah, S. (2013). Peran, Fungsi, Tujuan dan Manfaat Pembelajaran Matematika. Bandung: Citra Umbara. 
Hamdani. (2011). Strategi Belajar Mengajar. Bandung: Pustaka Setia.

Hariyanti. (2010). Upaya Meningkatkan Kemampuan Penalaran Matematika Siswa Kelas VII C SMP Negeri 2 Depok Sleman dalam Pembelajaran Matematika Melalui Pendekatan Investigasi (Fakultas Matematika dan Ilmu Pengetahuan Alam Universitas Negeri Yogyakarta). Yogyakarta: tidak diterbitkan.

Herman, et al. (2009). Pendidikan Matematika I. Bandung: Upi Press.

Huda. (2014). Model-Model Pengajaran dan Pembelajaran. Yogyakarta: Pustaka Pelajar.

Ibrohim. (2014). Penerapan Model NHT Untuk Meningkatkan Prestasi Belajar Siswa Pada Pembelajaran Matematika di Sekolah Dasar (Fakultas Matematika Universitas Negeri Yogyakarta). Yogyakarta: tidak diterbitkan.

Indaryanti. (2014). Penerapan Metode Inquiry Untuk Meningkatkan Prestasi Belajar Siswa Pada Pembelajaran Matematika di Sekolah Dasar (Fakultas Matematika Universitas Negeri Yogyakarta). Yogyakarta: tidak diterbitkan.

Isjoni. (2011). Metode Pembelajaran Rumpun Pembelajaran Efektif. Bandung: CV. Wacana Prima

Iskandar. (2009). Penelitian Tindakan Kelas. Jambi: Gaung Persada Press.
Karwati, et al. (2014). Manajemen KelasClassroom Management. Bandung: Alfabeta.

Kurikulum KTSP SDN Sukarajakulon I Tahun Pelajaran 2015/2016.

Kurniawati, M. (2012). Penerapan Pembelajaran Kooperatif Tipe TAI (Team Assisted Individualization) Untuk Meningkatkan Keaktifan Dan Prestasi Belajar Matematika Siswa Kelas V MI YAPPI Mulusan Paliyan Gunungkidul, Skripsi Sarjana pada Jurusan Pendidikan Guru Madrasah Ibtidaiyah Fakultas Tarbiyah Dan Keguruan Universitas Islam Negeri Sunan Kalijaga.Yogyakarta: tidak diterbitkan.

Kusnandar. (2007). Guru Profesional Implementasi (KTSP) dan Sukses dalam Sertifikasi Guru. Bandung: PT Raja Grafindo Persada.

Majid, A. (2013). Strategi Pembelajaran. Bandung: PT Remaja Rosdakarya.

Megawati, et al.. (2012). Model Pembelajaran Kooperatif Tipe Team Assisted Individualization (TAI) Dalam Meningkatkan Keaktifan Siswa Dan Hasil Belajar Akuntansi Siswa Kelas XI IPS 1SMA Negeri 1 Banjarnegara Tahun Ajaran 2011/2012. Banjarnegara: tidak diterbitkan.

Mughitsa, G. (2011). Pembelajaran Matematika di Kelas Akselerasi SMA Negeri 8 
Jakarta (Fakultas Ilmu

Tarbiyah dan Keguruan UIN

Syarif Hidayatullah. Jakarta: tidak diterbitkan.

Muslich, M. (2009). Pembelajaran Berbasis Komunikasi dan Kontekstual. Jakarta: Bumi Aksara.

Samani, et al.(2013). Konsep dan Model Pendidikan Karakter. Bandung: PT Remaja Rosdakarya.

Saud, U. S., et al. (2010). Inovasi Pendidikan. Bandung: Alfabeta.

Shampobiya (2011). Model Pembelajaran Kooperatif Tipe TAI (Team Assisted

Individualization). Bandung:

Citra Umbara.

Shoimin, A. (2014). 68 Model Pembelajaran Inovatif dalam Kurikulum 2013. Yogyakarta: Ar-Ruzz Media.

Siswanto, et al (2013). Penerapan Pembelajaran Kooperatif Tipe TAI (Team Assisted Individualization) Untuk Meningkatkan Hasil Belajar Pada Mata pelajaran Memelihara Sistem Bahan Bakar Bensin Siswa Kelas XI SMK Negeri 3 Boyolangu.Surabaya: tidak diterbitkan.

Slavin. (2011). Cooperative Learning Teori Riset dan Praktik (Edisi Terjemah). Bandung: Nusa Media.

Sudjana, N. (2009). Penilaian Hasil Proses Belajar Mengajar.
Bandung : PT Remaja Rosdakarya.

Sugiyono, (2014). Metode Penelitian Kuantitatif Kualitatif dan $R \& D$. Bandung: Alfabeta.

Sumantri, M. (2007). Perkembangan Peserta Didik. Jakarta: Universitas Terbuka.

Sukmadinata, N. (2010). Model Penelitian Pendidikan. Bandung: PT Remaja Rosdakarya.

Suprihatiningrum, J. (2013) Strategi Pembelajaran : Teori dan Aplikasi. Yogyakarta:Ar-ruzz Media.

Suyadi. (2010). Panduan Penelitian Tindakan Kelas. Yogyakarta: DIVA Press.

Syaripudin, T. et al. (2010). Landasan Pendidikan. Bandung : UPI PRESS.

(2013). Pedagogik Teoritis Sistematis. Bandung: Percikan Ilmu.

Tamim, A. F (2013). Penerapan Pembelajaran Tipe Numbered Heads Together (NHT) dengan Bantuan LKS Untuk Meningkatkan Hasil Belajar Matematika Pada Materi Bangun Ruang Sisi Datar Bagi Siswa Kelas VIII-4 MTs Al-Nathoniyyah. Semarang: tidak diterbitkan.

Uno, H. (2008). Perencanaan Pembelajaran. Jakarta: Bumi Aksara.

Widodo, et al. (2007). Pendidikan IPA $S D$. Bandung: Upi Press. 